\title{
A stable isotopic study of the diet of Potamonautes sidneyi (Brachyura: Potamonautidae) in two coastal lakes of the iSimangaliso Wetland Park, South Africa
}

\author{
N Peer ${ }^{1 *}$, R Perissinotto', NAF Miranda' and JL Raw ${ }^{1}$ \\ 'DST/NRF Research Chair in Shallow Water Ecosystems, C/o Department of Zoology, Nelson Mandela Metropolitan University, P.O. Box 77000, \\ Port Elizabeth, 6031
}

\begin{abstract}
Potamonautes sidneyi Rathbun 1904, is a dominant freshwater crab in KwaZulu-Natal, South Africa. Recent flood events in the iSimangaliso Wetland Park have allowed a substantial range expansion of this species, including previously hypersaline and desiccated areas. A stable isotope study was conducted to examine the feeding habits of the populations from Lake Sibaya and Mpophomeni Stream, two contrasting sites in the iSimangaliso Wetland Park. Juveniles from Mpophomeni Stream were more depleted in $\delta^{13} \mathrm{C}$ and more enriched in $\delta^{15} \mathrm{~N}$ compared to adults, indicating a more carnivorous diet and higher trophic position. A general shift in diet was observed at both sites, with consumption of aquatic invertebrates and sedimentary organic matter more prevalent in the wet summer months, while greater proportions of detritus and microphytobenthos were consumed in autumn/winter. No significant difference was observed between adults from the two sites despite the abiotic variations. The species appears to play a complex role in the trophic web, by acting as an intermediate consumer facilitating the flow of nutrients across levels and by breaking down decomposing organic matter, allowing for rapid recycling of nutrients within its ecosystem.
\end{abstract}

Keywords: diet, trophic role, stable isotopes, freshwater, brachyurans, opportunistic feeders

\section{INTRODUCTION}

Freshwater crabs comprise approximately one fifth of all brachyuran species (Yeo et al., 2008, Cumberlidge et al., 2009). They are widely consumed by humans and act as an intermediate host for food-borne diseases such as paragonimiasis (Appleton, 2012). These crabs are ecologically important, as their role in decomposition of detrital matter, combined with their large abundance and biomass (Dobson et al., 2007; Klaus and Plath, 2011), makes them a critical component of nutrient recycling in their ecosystems and ideal for use as bio-indicators (Steenkamp et al., 1994; Reinecke et al., 2003). In addition to this, crabs form a spatial link between aquatic and terrestrial habitats as a result of their amphibious lifestyle (Morris and Van Aardt, 1998).

The Natal River Crab, Potamonautes sidneyi Rathbun, 1904, is widespread throughout southern Africa occurring mainly in the lower and middle reaches of streams and rivers (Barnard, 1950). Potamonautes sidneyi has been described as having a stable population trend by the IUCN. It is a species of 'Least Concern' (LC) based on its wide habitat distribution and high degree of tolerance, especially to pollutants and habitat modification (Cumberlidge, 2008; Cumberlidge et al., 2009).

Despite the ecological importance of $P$. sidneyi (Purves, 1991; Dyer et al., 2013), no work has been done on the species in terms of population studies, diet, trophic position and tolerance to anthropogenic and natural disturbances or habitat modification. While Reavell and Cyrus (1989) classified the species as a 'benthic scavenger', Dobson (2004), in a statement referring to all African freshwater crabs, suggested that in addition to this they had a preference for plant-based detritus. Hill and O'Keeffe

\footnotetext{
* To whom all correspondence should be addressed. × 0815627255; e-mail: peer.nasreen@gmail.com Received 15 January 2015; accepted in revised form 17 June 2015
}

(1992) examined the diet of P. perlatus H. Milne Edwards 1837, a related species from the Eastern Cape (South Africa), using gut content analysis. They found that smaller individuals, i.e. < $40 \mathrm{~mm}$ carapace widest width (CWW), were herbivorous, also feeding on aquatic invertebrates, while larger individuals of the species (> $40 \mathrm{~mm} \mathrm{CWW}$ ) were detritivorous, feeding mainly on leaf litter, detritus and algae.

The iSimangaliso Wetland Park is a UNESCO World Heritage Site in northern KwaZulu-Natal on the east coast of South Africa. It contains three Ramsar Wetlands of International Importance, two of which are considered in this study. These are Lake St Lucia, Africa's largest estuarine system (Whitfield et al., 2013), and Lake Sibaya, southern Africa's largest natural freshwater lake (Allanson, 1979). The region is characterised by wet summer months with high rainfall between October and March and dry winter months between May and August with minimal rainfall (Whitfield and Taylor, 2009). Rainfall in the iSimangaliso Wetland Park has increased dramatically since the end of 2011, with above-average precipitation causing floods in the summers of both 2012 and 2013. This, together with the Mfolozi re-connection (Whitfield et al., 2013), has resulted in substantially decreased salinity levels and increased water depths throughout Lake St Lucia. Throughout the region, the increased freshwater supply has led to the introduction of a number of freshwater taxa into previously saline systems (Lake St Lucia) and a range expansion in their distribution elsewhere ( $\mathrm{Nel}$ et al., 2015). Potamonautes sidneyi is expected to spread through the St Lucia estuarine lake as the system shifts towards freshwater-dominated phases from hypersaline states (Whitfield et al., 2013). The species is one of three recorded freshwater brachyuran species found around the lake, the others being the potamonautid Potamonautes isimangaliso Peer and Gouws, 2015 and the varunid Varuna litterata (Fabricius, 1798). Potamonautes sidneyi could become dominant at many sites, affecting the associated ecosystems, both terrestrial and aquatic. 
The aim of this study was to compare the diet of adult and juvenile $P$. sidneyi occupying different habitats in two coastal lakes of the iSimangaliso Wetland Park, Lake Sibaya and Lake St Lucia (Fig. 1). By relating the carbon and nitrogen signatures of $P$. sidneyi individuals to those of potential food items, it is possible to determine food sources and trophic position, respectively (Post, 2002). Stable isotope analysis (SIA) is used to examine the diet of an organism on a long-term basis, as the unique carbon and nitrogen values of food items are incorporated into the tissue of the target species. Gut content analysis (GCA) was also used to provide insight into the most recent dietary behaviour of individuals. It was hypothesized that $P$. sidneyi displays an ontogenetic diet shift indicated by different isotope values and trophic positions, most likely due to changes in dietary requirements and also variation in habitat occupation by juveniles and adults. It was further hypothesized that seasonal shifts in diet and trophic position would be found as a consequence of variation in available food items.

\section{MATERIALS AND METHODS}

Two sites were selected: the Mpophomeni Stream (275 $57^{\prime} 7.17^{\prime \prime} \mathrm{S}$ $32^{\circ} 22^{\prime} 37.21^{\prime \prime E}$ ) located on the western shore of False Bay (Lake St Lucia); and the eastern shore of Lake Sibaya $\left(27^{\circ} 23^{\prime} 49.28^{\prime \prime} \mathrm{S}\right.$ $\left.32^{\circ} 42^{\prime} 42.17^{\prime \prime} \mathrm{E}\right)$ (Fig.1).

These systems vary in physico-chemical properties such as salinity, hydrodynamics and substrate characteristics (Table 1). Lake Sibaya hosts a number of originally marine and estuarine species as a result of its past connection to the marine environment. These species are now uniquely adapted to freshwater conditions (Bruton, 1975). The lake has an average depth of 13 $\mathrm{m}$ with a steep profile through the littoral zone (Bruton, 1980). At the time of the study, the level of the lake was low according to previous records (Allanson, 1979). While there was no overhanging vegetation at the sampling sites, fringing vegetation at the water's edge included Phragmites sp., Typha latifolia and Cyperus sp. Submerged macrophytes, such as Stuckenia spp. were dominant close to shore. The Mpophomeni Stream is a small brackish forest stream that persists even during the dry season. It is connected to the saline waters of False Bay via a Phragmites mauritianus marsh. The stream is shaded by sand forest trees, many of which belong to the Fabaceae family, and some are unique to this habitat (Kirkwood and Midgley, 1999). Fringing vegetation included unidentified grasses and Phragmites. Specimens were collected both in the wet summer and dry autumn/winter months, i.e., December 2012 - January 2013 and May - June 2013, respectively. Physico-chemical variables, including conductivity, temperature, dissolved oxygen, turbidity and $\mathrm{pH}$, were recorded using a YSI 6600V2 multiprobe system. Samples collected included crabs and potential food items, such as juvenile fish, bivalves, gastropods, particulate organic matter (POM), microphytobenthos (MPB), sedimentary organic matter (SOM), detritus, macroalgae and fringing vegetation. All samples were frozen immediately upon collection until they were processed in the lab.

\section{Sample collection and processing}

Crabs collected ranged in carapace widest width (CWW) between 9 and $57 \mathrm{~mm}$ and were dug out of burrows using a shovel or netted out of the sediment-water interface. Specimens with a CWW $<30 \mathrm{~mm}$ were classified as juveniles, while individuals with a CWW $>30 \mathrm{~mm}$ were recorded as adults. No

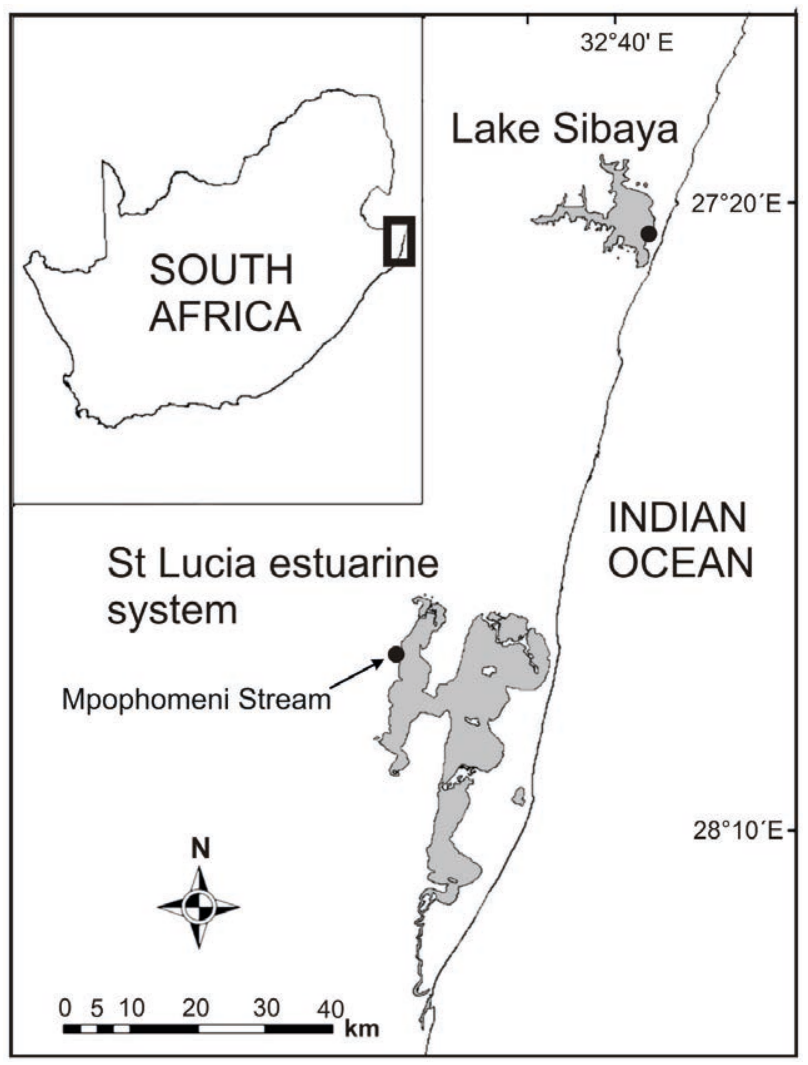

Figure 1

Map showing Lake Sibaya and Lake St Lucia, with black dots indicating sampling locations (adapted from Miranda and Perissinotto, 2012)

\begin{tabular}{|c|c|c|c|c|}
\hline \multicolumn{5}{|c|}{$\begin{array}{l}\text { TABLE } 1 \\
\begin{array}{l}\text { Physico-chemical parameters for both sampling sites in the wet and dry seasons of 2012-2013 }\end{array}\end{array}$} \\
\hline & \multicolumn{2}{|c|}{ Mpophomeni Stream } & \multicolumn{2}{|c|}{ Lake Sibaya } \\
\hline & \multicolumn{2}{|c|}{$27^{\circ} 57^{\prime} 7.17^{\prime \prime} \mathrm{S} 32^{\circ} 22^{\prime} 37.21^{\prime \prime} \mathrm{E}$} & \multicolumn{2}{|c|}{$27^{\circ} 23^{\prime} 49.28^{\prime \prime} \mathrm{S} 32^{\circ} 42^{\prime} 42.17^{\prime \prime} \mathrm{E}$} \\
\hline & Wet & Dry & Wet & Dry \\
\hline Temperature $\left({ }^{\circ} \mathrm{C}\right)$ & 26.3 & 19.7 & 27.2 & 22.8 \\
\hline Salinity & 7.6 & 9.1 & 0.4 & 0.4 \\
\hline Turbidity (NTU) & 26.8 & 2.7 & 5.7 & 0.0 \\
\hline 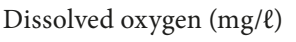 & 8.5 & 10.0 & 8.0 & 8.7 \\
\hline $\mathrm{pH}$ & 8.5 & 7.4 & 8.8 & 7.6 \\
\hline
\end{tabular}


juveniles were found at Lake Sibaya. Juvenile fish were collected using an epibenthic sled (100 $\mu \mathrm{m}$ mesh size). Tissue samples were collected from the chelae of each crab, and from the dorsal muscle of juvenile fish to prevent the inclusion of lipid content.

Bivalve and gastropod samples were extracted by cracking open the shell and removing the muscle tissue. The samples were then washed in a solution of methanol:chloroform: distilled water (2:1:0.8) for approximately $3 \mathrm{~h}$ to remove any lipid content. As the entire organism was used, samples were further rinsed in $2 \% \mathrm{HCl}$ to remove biogenic compounds.

POM was collected by filtering triplicate $20 \ell$ buckets of water onto pre-combusted Whatman GF/F filters $(0.7 \mu \mathrm{m}$ mesh size). Sediment containing MPB was suspended in filtered water, which was then filtered onto pre-combusted GF/ Fs once the sediment had settled out of the water column. The POM and MPB filters were washed with $2 \% \mathrm{HCl}$ to remove any sediment and biogenic compounds. Sediment collected from both sites was also rinsed in $2 \% \mathrm{HCl}$ before further processing.

Macrophytes and algae were rinsed thoroughly in distilled water to remove any sediment, epiphytes or epifauna.

The brachyuran, gastropod, bivalve, fish, plant and algae samples were dried in an oven at $50^{\circ} \mathrm{C}$ for $48 \mathrm{~h}$ before being crushed into a fine powder using a mortar and pestle. Between 0.6 and $0.7 \mathrm{mg}$ of animal matter and $1 \mathrm{mg}$ of plant and algal matter was extracted and placed into $5 \times 8 \mathrm{~mm}$ tin capsules.

\section{Isotope analysis}

Samples consisting of 3-10 replicates were analysed at the Stable Light Isotope Unit (Department of Archaeology, University of Cape Town). They were combusted in a Flash EA 1112 series elemental analyser (Thermo Finnigan, Italy). Gases were passed through a Conflo III gas control unit (Thermo Finnigan, Germany) to the isotope ratio mass spectrometer (Delta Plus XP IRMS, Thermo Electron, Germany) to obtain isotope ratios, which were standardised using the equation of Peterson and Fry (1987):

$$
\delta \mathrm{X}=\left[\left(R_{\text {sample }} / R_{\text {standard }}\right)-1\right] \times 1000
$$

where: $\delta \mathrm{X}$ represents variation from a standard in \%o (per mille) and X represents the heavier isotope. $R_{\text {sample }}$ is the ratio of ${ }^{13} \mathrm{C} /{ }^{12} \mathrm{C}$ or ${ }^{15} \mathrm{~N} /{ }^{14} \mathrm{~N}$ of the sample and $R_{\text {standard }}$ is ${ }^{13} \mathrm{C} /{ }^{12} \mathrm{C}$ of Vienna PDB or ${ }^{15} \mathrm{~N} /{ }^{14} \mathrm{~N}$ of atmospheric nitrogen. A more positive value is thus 'isotopically enriched' and contains a higher proportion of the heavier isotope (Vander Zanden and Rasmussen, 1999).

\section{Gut content analysis}

The foreguts of 10-20 individual crabs from each site were excised for GCA on each sampling occasion. These were frozen to prevent further digestion and preserved for laboratory analysis, where they were examined using a dissecting microscope. All contents were identified and quantified using a counting grid (Hynes, 1950) under 30x magnification and the volumetric proportion of each food item was recorded.

\section{Data analysis and determination of trophic position}

To determine if isotope values were significantly different between seasons, juvenile and adult crabs as well as the various food sources, MANOVAs were run in Statistica 11. All assumptions of randomly-selected data, normally distributed data and equal variances were met.

Mixed models were constructed using the Stable Isotope Analysis in R (SIAR) v4.0 package of Parnell et al. (2010), in order to determine the proportion of different items in the diet of each population. Gut content analysis results were used to eliminate some potential but unlikely food sources to improve the accuracy and precision of the mixing models. The trophic position of sampled brachyurans was estimated on the basis that consumer $\delta^{15} \mathrm{~N}$ levels are enriched by $3.4 \%$ ( $\pm 0.2 \mathrm{SD}$ ) (Minagawa and Wada, 1984; Post, 2002) and $\delta^{13} \mathrm{C}$ levels are enriched by $1 \%$ ( $\left.\pm 0.5 \mathrm{SD}\right)$, due to metabolic processes, such as respiration (Minagawa and Wada, 1984; Hobson et al., 2002). There is great variability in enrichment factors, particularly the shift in nitrogen, between consumers and their diet where the enrichment factor ranges from -0.8 to $5.9 \%$ (McCutchan et al., 2003).

The trophic position of organisms can be compared between sites using the standardising equations of Vander Zanden and Rasmussen (1999):

$$
\mathrm{TP}=\lambda+\left(\delta^{15} \mathrm{~N}_{\mathrm{c}}-\delta^{15} \mathrm{~N}_{\text {base }}\right) / \Delta_{\mathrm{n}}
$$

where: $\delta^{15} \mathrm{~N}_{c}$ is the consumer nitrogen isotopic composition, $\delta^{15} \mathrm{~N}_{\text {base }}$ is that of the food base, estimated from the carbon ratios of all primary consumers in the system (Vander Zanden and Rasmussen, 1999), $\lambda$ is the trophic position of the base ( $\lambda$ $=2$ for primary consumers) and $\Delta_{\mathrm{n}}$ is the estimate of the average increase in $\Delta^{15} \mathrm{~N}$ per trophic position. A value of 3.4 was assigned to $\Delta^{15} \mathrm{~N}$, following Minagawa and Wada (1984), as it is not habitat-specific and is widely applied to isotope studies of crustaceans and other invertebrate taxa.

\section{RESULTS}

\section{$\delta^{13} \mathrm{C}$ and $\delta^{15} \mathrm{~N}$ values of sources}

There was a significant difference between isotope values of food sources, both at the Mpophomeni Stream (wet: Pillai's Trace = $1.999, F=2190.3, p<0.05$; dry: Pillai's Trace $=1.98, F=145.1$, $p<0.05)$ and Lake Sibaya (wet: Pillai's Trace $=1.991, F=181.8$, $p<0.05$; dry: Pillai's Trace $=1.954, F=42.7, p<0.05$ ), allowing for high source discrimination by the mixing model used.

At Mpophomeni Stream (Fig. 2, Table 2), $\delta^{13} \mathrm{C}$ values ranged from -29.07 ( \pm 0.32) for Melanoides tuberculata (Müller, 1774) to $-6.48( \pm 0.76)$ for MPB in the wet season, while more depleted $\delta^{13} \mathrm{C}$ values prevailed in the dry season. In terms of $\delta^{15} \mathrm{~N}$, fringing vegetation collected from around the stream had the most depleted value of -0.34 ( \pm 0.03 ), while the Mozambique tilapia, Oreochromis mossambicus (Peters, 1852), had the most enriched value of $18.12( \pm 0.08)$. The same was true for the dry season, with $O$. mossambicus displaying the most enriched nitrogen value of 17.93 ( \pm 0.91$)$, while detritus was the least nitrogen-enriched source with a value of $-3.47( \pm 2.86)$.

Unlike in the Mpophomeni Stream, the range of $\delta^{13} \mathrm{C}$ values at Lake Sibaya was relatively low in both wet and dry seasons (Fig. 2, Table 3). Cladophora sp. algae had the most enriched $\delta^{13} \mathrm{C}$ signature in both seasons, with values of -9.50 $( \pm 0.29)$ and $-8.35( \pm 0.11)$, respectively. The bivalve Corbicula fluminalis (Müller 1774) had the most depleted carbon signature, with a value of $-24.13( \pm 0.09)$ in the wet season, but was not found at the site in the dry season. Instead, POM displayed the most depleted carbon signature with a value of -24.62 ( \pm 0.17$)$. Cladophora sp. algae had the most depleted $\delta^{15} \mathrm{~N}$ in both seasons, with a value of $1.62( \pm 0.29)$ in the wet 
and $0.12( \pm 0.22)$ in the dry part of the year. In the wet season, MPB had the highest $\delta^{15} \mathrm{~N}$ value of $10.95( \pm 0.00)$. The fish larvae had a similar signature, with a value of $10.06( \pm 0.06)$, while in the dry season adult $O$. mossambicus were the most enriched in nitrogen, with a value of $9.78( \pm 0.12)$.

\section{$\delta^{13} \mathrm{C}$ and $\delta^{15} \mathrm{~N}$ values of Potamonautes sidneyi}

At Mpophomeni, there was a significant difference between values of juveniles and adults in both wet (Pillai's Trace $=0.998$, $F=659.4, p<0.05$ ) and dry seasons (Pillai's Trace $=0.980$,

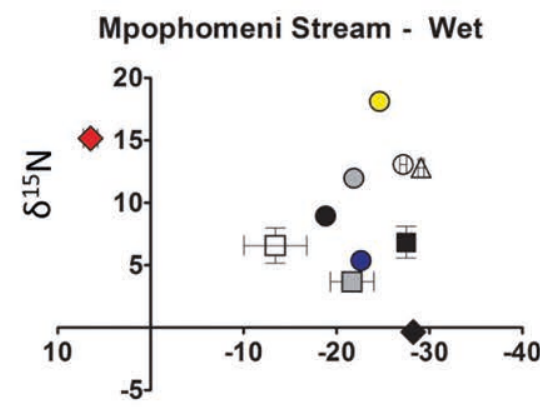

Lake Sibaya - Wet

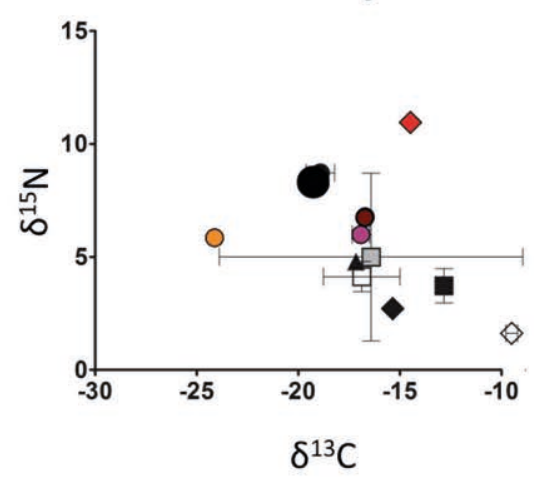

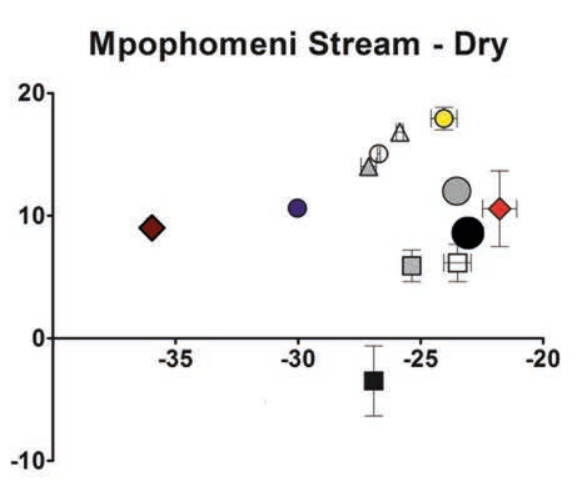

Lake Sibaya - Dry

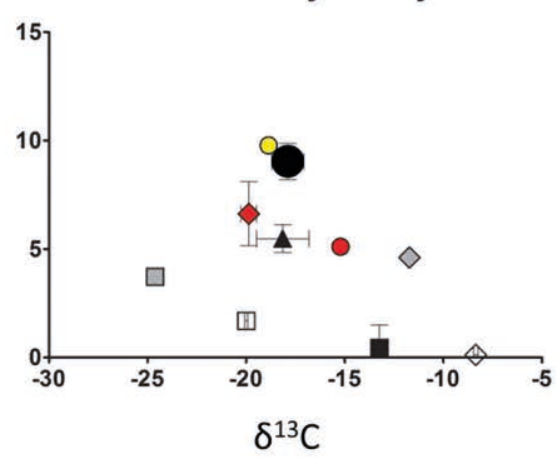

\section{Consumers}

Crab-Potamonautes - adult Crab - Potamonautes - juvenile

Crab - Hymenosoma

Fish-Oreochromis

Shrimp-Macrobrachium

Amphipod - Afrochiltonia

Amphipod - Melita

Isopod-Dies

Bivalve - Corbicula

- Snail-Tarebia

$\triangle$ Snail-Melanoides

$\triangle$ Snail-Melanoides (with Cladophora)

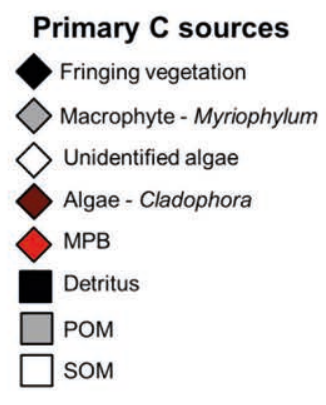

Figure 2

${ }^{15} \mathrm{~N}$ and $\delta^{13} \mathrm{C}$ biplots of dietary items and Potamonautes sidneyi from Mpophomeni Stream and Lake Sibaya in both the wet and dry seasons. Error bars denote SD; $P O M=$ particulate organic matter, $S O M=$ sedimentary organic matter, $M P B=$ microphytobenthos

\begin{tabular}{|c|c|c|c|c|}
\hline \multicolumn{5}{|c|}{$\begin{array}{l}\text { TABLE } 2 \\
\text { Mean } \delta^{13} \mathrm{C} \text { and } \delta^{15} \mathrm{~N} \text { signatures (with standard deviation in brackets) of all potential food items and the target species } \\
\text { Potamonautes sidneyi from the Mpophomeni Stream in the wet and dry seasons ( } n=5 \text { for each source and target) }\end{array}$} \\
\hline \multirow{2}{*}{ Sources } & \multicolumn{2}{|c|}{ Wet } & \multicolumn{2}{|c|}{ Dry } \\
\hline & $\delta^{15} \mathrm{~N}$ & $\delta^{13} \mathrm{C}$ & $\delta^{15} \mathrm{~N}$ & $\delta^{13} \mathrm{C}$ \\
\hline Oreochromis mossambicus & $18.12( \pm 0.08)$ & $-24.60( \pm 0.06)$ & $17.93( \pm 0.91)$ & $-24.05( \pm 0.53)$ \\
\hline Melanoides tuberculata & $12.80( \pm 0.09)$ & $-29.07( \pm 0.32)$ & $16.83( \pm 0.11)$ & $-25.85( \pm 0.14)$ \\
\hline M. tuberculata with algae & - & - & $14.02( \pm 0.44)$ & $-27.12( \pm 0.31)$ \\
\hline Macrobrachium equidens & $13.07( \pm 0.65)$ & $-27.15( \pm 0.37)$ & $15.05( \pm 0.08)$ & $-26.71( \pm 0.05)$ \\
\hline Melita zeylanica & $5.38( \pm 0.13)$ & $-22.61( \pm 0.04)$ & $10.62( \pm 0.14)$ & $-30.03( \pm 0.12)$ \\
\hline Fringing vegetation & $-0.34( \pm 0.03)$ & $-28.24( \pm 0.05)$ & $-0.35( \pm 0.00)$ & $-28.29( \pm 0.00)$ \\
\hline Cladophora sp. & - & - & $9.08( \pm 0.10)$ & $-36.00( \pm 0.18)$ \\
\hline MPB & $15.16( \pm 0.00)$ & $-6.48( \pm 0.76)$ & $10.57( \pm 3.09)$ & $-21.78( \pm 0.70)$ \\
\hline Detritus & $6.84( \pm 1.26)$ & $-27.47( \pm 0.61)$ & $-3.47( \pm 2.86)$ & $-26.91( \pm 0.13)$ \\
\hline POM & $3.69( \pm 0.11)$ & $-21.66( \pm 2.33)$ & $5.92( \pm 1.27)$ & $-25.36( \pm 0.07)$ \\
\hline SOM & $6.57( \pm 1.40)$ & $-13.40( \pm 3.37)$ & $6.16( \pm 1.53)$ & $-23.49( \pm 0.55)$ \\
\hline \multicolumn{5}{|l|}{ Targets } \\
\hline P. sidneyi adults & $8.95( \pm 0.14)$ & $-18.8( \pm 0.04)$ & $8.76( \pm 0.04)$ & $-22.39( \pm 0.64)$ \\
\hline P. sidneyi juveniles & $11.87( \pm 0.15)$ & $-21.93( \pm 0.12)$ & $12.03( \pm 0.28)$ & $-23.57( \pm 0.07)$ \\
\hline
\end{tabular}


TABLE 3

$\delta^{13} \mathrm{C}$ and $\delta^{15} \mathrm{~N}$ signatures (with standard deviation in brackets) of all potential food items and the target species Potamonautes sidneyi from Lake Sibaya in the wet and dry season ( $n=5$ for each source and target)

\begin{tabular}{|c|c|c|c|c|}
\hline \multirow{2}{*}{ Sources } & \multicolumn{2}{|c|}{ Wet } & \multicolumn{2}{|c|}{ Dry } \\
\hline & $\delta^{15} \mathrm{~N}$ & $\delta^{13} \mathrm{C}$ & $\delta^{15} \mathrm{~N}$ & $\delta^{13} \mathrm{C}$ \\
\hline Oreochromis mossambicus & - & - & $9.78( \pm 0.12)$ & $-18.86( \pm 0.04)$ \\
\hline Corbicula fluminalis & $5.85( \pm 0.01)$ & $-24.13( \pm 0.09)$ & - & - \\
\hline Tarebia granifera & $4.79( \pm 0.00)$ & $-17.17( \pm 0.00)$ & $5.48( \pm 0.64)$ & $-18.15( \pm 1.33)$ \\
\hline Afrochiltonia capensis & - & - & $5.11( \pm 0.32)$ & $-15.21( \pm 0.04)$ \\
\hline Hymenosoma projectum & $5.99( \pm 0.20)$ & $-16.93( \pm 0.43)$ & - & - \\
\hline Dies monodi & $6.77( \pm 0.12)$ & $-16.71( \pm 0.09)$ & - & - \\
\hline Fish larvae & $10.06( \pm 0.06)$ & $-22.49( \pm 0.00)$ & - & - \\
\hline Egg mass & - & - & $3.57( \pm 0.17)$ & $-14.45( \pm 0.06)$ \\
\hline Cladophora sp. & $1.62( \pm 0.29)$ & $-9.50( \pm 0.29)$ & $0.12( \pm 0.22)$ & $-8.35( \pm 0.11)$ \\
\hline Juncus kraussii & $3.69( \pm 0.09)$ & $-12.66( \pm 0.02)$ & $0.09( \pm 1.67)$ & $-11.68( \pm 0.03)$ \\
\hline Myriophylum sp. & $2.71( \pm 0.11)$ & $-15.36( \pm 0.14)$ & $4.61( \pm 0.32)$ & $-11.71( \pm 0.09)$ \\
\hline MPB & $10.95( \pm 0.00)$ & $-14.49( \pm 0.00)$ & $6.63( \pm 1.48)$ & $-19.87( \pm 0.40)$ \\
\hline Detritus & $3.72( \pm 0.77)$ & $-12.84( \pm 0.23)$ & $0.44( \pm 1.06)$ & $-13.24( \pm 0.31)$ \\
\hline POM & $5.00( \pm 3.72)$ & $-16.43( \pm 7.47)$ & $3.72( \pm 0.03)$ & $-24.62( \pm 0.17)$ \\
\hline SOM & $4.13( \pm 0.67)$ & $-16.88( \pm 1.88)$ & $1.69( \pm 0.01)$ & $-19.99( \pm 0.08)$ \\
\hline \multicolumn{5}{|l|}{ Target } \\
\hline P. sidneyi adults & $8.71( \pm 0.32)$ & $-18.92( \pm 0.69)$ & $9.02( \pm 0.84)$ & $-17.88( \pm 0.81)$ \\
\hline
\end{tabular}

$F=49.3, p=0.02$ ), with juveniles exhibiting a more enriched $\delta^{15} \mathrm{~N}$ and more depleted $\delta^{13} \mathrm{C}$ signature (Table 2). Juvenile carbon values ranged from $-21.93( \pm 0.12)$ in the wet to -23.57 $( \pm 0.07)$ in the dry season, while adults displayed a shift from a carbon value of $-18.8( \pm 0.04)$ in the wet to $-22.39( \pm 0.64)$ in the dry season (Fig. 2). Regarding nitrogen, juvenile values did not increase significantly from the wet to the dry season $(F=$ $0.562, p=0.508)$, exhibiting values of $11.97( \pm 0.00)$ and 12.03 $( \pm 0.28)$, respectively. The same was observed for adults, where values ranged from $8.95( \pm 0.14)$ in the wet to $8.79( \pm 0.00)$ in the dry season and were not significantly different $(F=3.101$, $p=0.153)$ (Fig. 2).

At Lake Sibaya (Fig. 2, Table 3), no juveniles were found during either sampling period. Adults had statistically similar isotope values to those from Mpophomeni Stream in the wet season (Pillai's Trace $=0.264, F=0.894, p=0.465$ ), while dry season values $(-17.88 \pm 0.81)$ differed significantly from those of the Mpophomeni Stream counterparts (Pillai's Trace $=0.938$, $F=22.504, p=0.02$ )

\section{Mixing models}

At the Mpophomeni site (Fig. 3), during the wet season juveniles predominantly ingested and assimilated the amphipod Melita zeylanica Stebbing, 1904, the penaeid shrimp Macrobrachium equidens (Dana, 1852) and SOM. Adults had elevated proportions of Afrochiltonia capensis (Barnard, 1916) amphipods and SOM, together contributing up to 55\% (50\% C.I.) of adult assimilated diet. Detritus appeared to contribute minimally to the assimilated diet of adults. In the dry season, both adults and juveniles largely assimilated amphipods and
Cladophora sp. algae, which together constituted approximately $50 \%$ (50\% C.I.) of the total assimilated diets. However, while adults assimilated large amounts of detritus, the opposite was seen in juvenile individuals, which had greater proportions of MPB and lower detrital isotope values.

The bivalve C. fluminalis contributed 40 to $50 \%$ (50\% C.I.) of the diet of adult $P$. sidneyi collected from Lake Sibaya in the wet season, while elevated isotopic values of SOM and Cladophora sp. were also recorded (Fig. 4). In the dry season, however, MPB and gastropods together contributed roughly up to $70 \%$ (50\% C.I.) of adult assimilated diet.

\section{Gut content analysis}

The guts of Mpophomeni juveniles had a greater percentage of animal tissue in the wet season compared to the dry season (Fig. 5A), ranging from $47 \%$ to $15 \%$, respectively. Percentage of sediment increased from $11 \%$ in the wet season to $32 \%$ in the dry season, while both algal filaments and MPB increased by approximately $10 \%$ from the wet to the dry season.

Adults (Fig. 5B) contained mostly sedimentary and animal matter, including fatty tissue and exoskeletal remains. Animal matter comprised $17 \%$ of the total diet in the wet season and increased to $27 \%$ of the total diet in the dry season. Detritus was also prevalent and constituted 15\% (dry) to 22\% (wet) of the total gut contents, showing a decrease from the wet to the dry season.

Adults from Lake Sibaya (Fig. 6) consumed mostly detritus (31\%), animal tissue $(29 \%)$ and sediment $(33 \%)$ during the wet season. The contribution of both detritus and sediment to gut content decreased by $18 \%$ and $6 \%$, respectively, from the wet to 

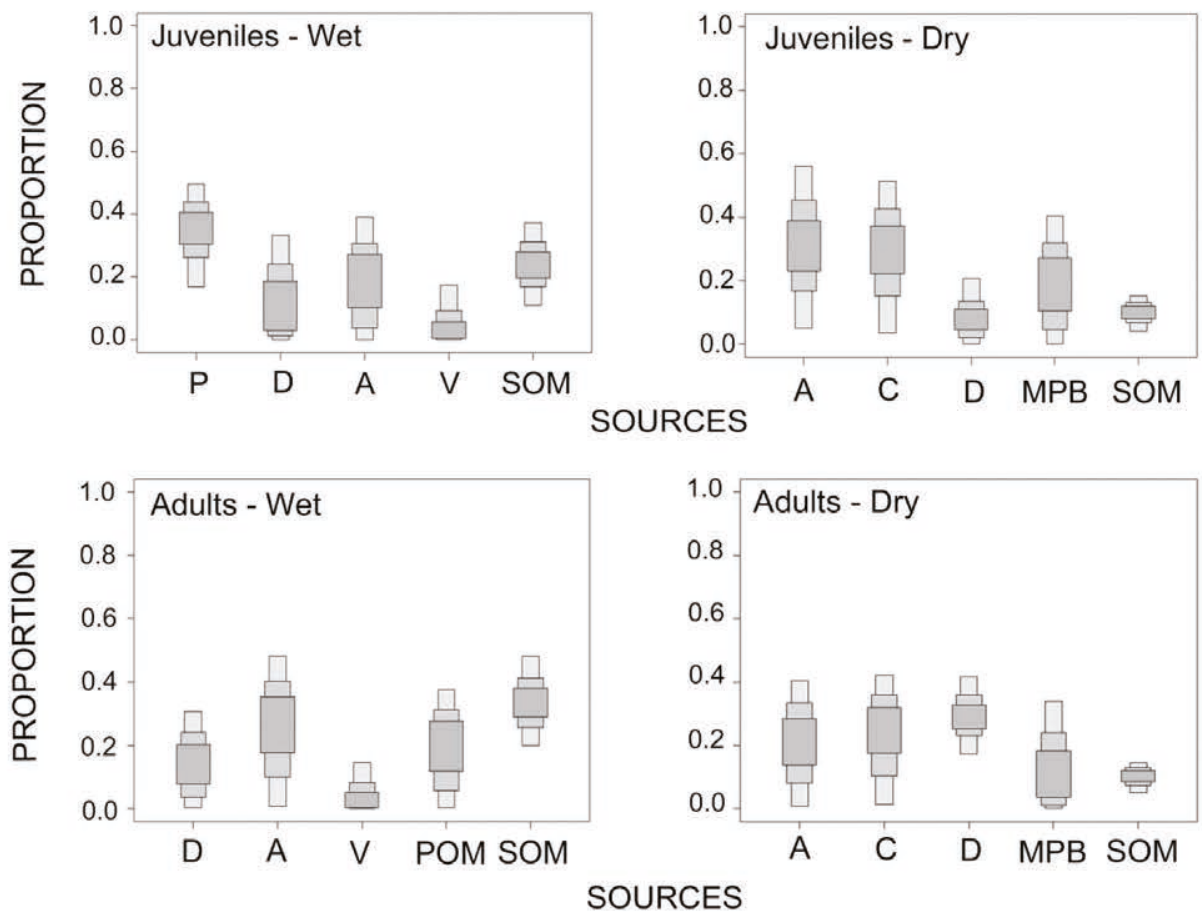

Figure 3

Mixed models based on $\delta^{13} \mathrm{C}$ and $\delta^{15} \mathrm{~N}$ signatures for adults $(C W W>30 \mathrm{~mm}$ ) and juveniles $(C W W<30 \mathrm{~mm})$ P. sidneyi from the Mpophomeni Stream in the wet and dry season. The proportions are plotted at $95 \%, 75 \%$ and $50 \%$ credibility intervals. $P$ - Macrobrachium equidens penaeid shrimp, $D$ - detritus, A - Melita zeylanica amphipod, $V$ - fringing vegetation, $C$ - Cladophora sp. algae, POM - particulate organic matter, SOM - sedimentary organic matter, MPB - microphytobenthos.

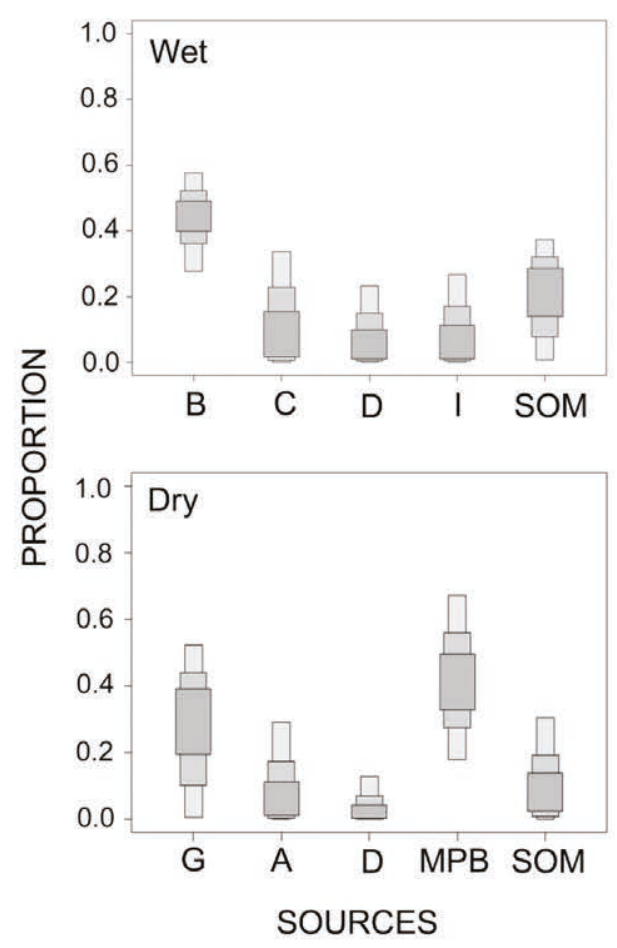

Figure 4

Mixed models based on $\delta^{13} \mathrm{C}$ and $\delta^{15} \mathrm{~N}$ signatures for adult P. sidneyi from Lake Sibaya in wet and dry seasons. The proportions are plotted at 95\%, $75 \%$ and $50 \%$ credibility intervals. B - Corbicula fluminalis bivalve, CCladophora sp. algae, $D$ - detritus, I - Dies monodi isopod, $G$ - Tarebia granifera gastropod, $A$ - Afrochiltonia capensis amphipod, SOM sedimentary organic matter, MPB - microphytobenthos.
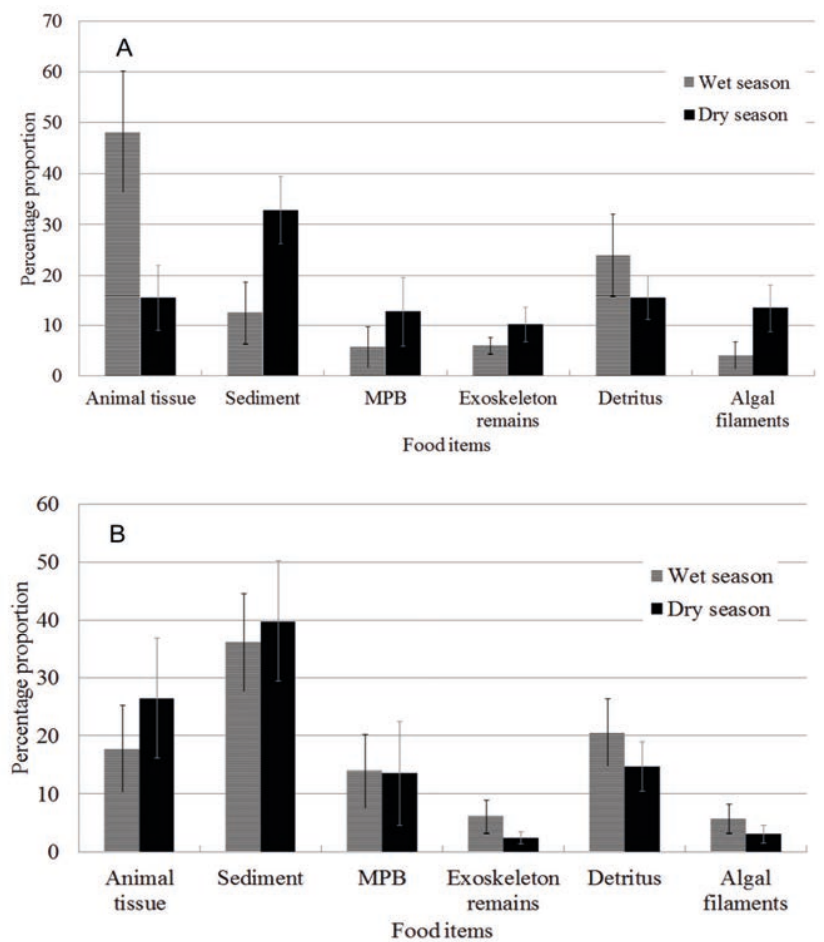

Figure 5

Percentage composition of gut contents for ( $A$ ) juveniles and (B) adults P. sidneyi in the wet and dry season at the Mpophomeni Stream. Error bars represent standard error 
the dry season. An increase of $15 \%$ and $9 \%$ was observed in the presence of MPB and algal filaments, respectively, from the wet to the dry season.

\section{Trophic position}

Juveniles at Mpophomeni Stream had a higher trophic position (Table 4) than adults, which were located approximately one trophic level below juveniles. Trophic positions of adults at Lake Sibaya (Table 4) were higher than those of adults at Mpophomeni Stream. The trophic position of adults from Lake Sibaya did not change with season.

\section{DISCUSSION}

Although tropical freshwater crabs are traditionally characterised as being largely herbivorous and detritivorous (Hill and O'Keeffe, 1992; Burress et al., 2013), they have been shown to feed opportunistically and even display cannibalistic tendencies (Dobson, 2004; Marijnissen et al., 2009; Burress et al., 2013). The dynamic dietary composition of $P$. sidneyi between sites and seasons indicates plasticity in feeding behaviour and the opportunistic tendencies of these populations. This is in partial agreement with the idea that the species has a scavenging nature (Reavell and Cyrus, 1989; Dobson, 2004). However, the extent to which aquatic invertebrates form part of the diet of this species emphasises its multidimensional role and importance in the trophic food web. Primarily considered to be largely herbivorous and detritivorous, $P$. sidneyi has so far been regarded as a recycling component of these trophic webs, where leaf litter and detritus are broken down during the feeding process, thus facilitating decomposition and nutrient recycling. While the presence of detritus and algal matter in the guts of $P$. sidneyi individuals bears testament to this, the significant consumption of aquatic invertebrates implies an additional consumer role for the species. Considering the nitrogen isotopic ratios obtained in this study, the $P$. sidneyi populations sampled

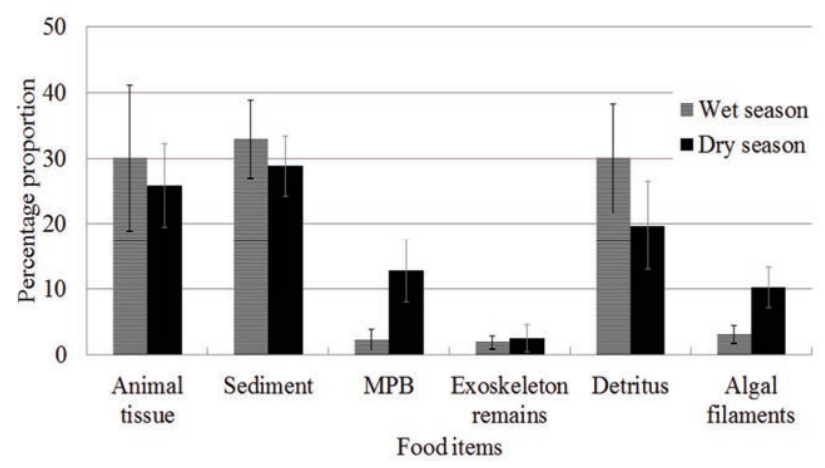

Figure 6

Percentage composition of adults P. sidneyi in a) the wet and b) dry season at Lake Sibaya. Error bars represent standard error. are not the apex consumers of their respective food webs. The fish $O$. mossambicus and various other macrobenthic organisms display the most enriched nitrogen values, while $P$. sidneyi displays $\delta^{15} \mathrm{~N}$ ratios intermediate to these higher consumers and the producers. The transitional role of the genus in many food and trophic webs is discussed by Dobson (2004).

St Lucia is currently inhabited by at least 14 other brachyuran species (Peer et al., 2014). With the predicted spread of $P$. sidneyi through the lake, it is expected that they will interact with other species, possibly competing for space and food. It is therefore essential to understand the ecological role that the species plays. Within Lake Sibaya, $P$. sidneyi co-exists with Hymenosoma projectum (Dawson and Griffiths, 2012), another brachyuran species with freshwater tolerance (Forbes and Hill, 1969). However, the two species occupy separate niches, with $H$. projectum found predominantly below the water level burrowed in sandy patches, while $P$. sidneyi occurs beneath clumps of detritus and algae or in burrows along the sandy banks. They do not appear to interact directly. The absence of $P$. sidneyi juveniles from the site throughout the year is unusual. However, bearing in mind the apparent preference of juveniles for the profundal zone, it is possible that they occur at greater depths in the lake due to its low turbidity (Table 1).

In Lake St Lucia, juvenile P. sidneyi of the Mpophomeni Stream population had a high $\delta^{15} \mathrm{~N}$ signature, indicating that they occupy a higher trophic position than adults. In support of the first hypothesis, this implies that there is an ontogenetic diet shift and highlights the occupation of two different trophic roles by one species at different stages of its life cycle. A more enriched $\delta^{15} \mathrm{~N}$ often indicates a greater carnivorous tendency (Post, 2003). The ${ }^{13} \mathrm{C}$ depletion of juvenile crabs relative to adults seen in the wet season can be attributed to the greater dependence of juveniles on pelagic penaeid shrimps, which have been feeding on $\delta^{13} \mathrm{C}$-depleted food sources such as detritus (Table 2). Ontogenetic shifts in the diet of aquatic organisms are widely documented in the literature, with the most apparent reason for such shifts being a change in dietary requirement of adults from the juvenile life stage (Werner and Gilliam, 1984). Williams (1965) suggested that larger animals (adults) move slower than smaller animals (juveniles) and are thus less likely to actively pursue animal prey. This author also showed that differentially-sized individuals of a population display variation in resource-utilisation abilities. However, habitat differences between adults and juveniles may further explain a dietary shift between ontogenetic phases. A study by France (1995) showed that pelagic algae are generally more $\delta^{13} \mathrm{C}$-depleted in relation to benthic algae and that this difference was significant enough to be transmitted to consumers in these aquatic environments. Additionally, adult crabs tend to remain along the edges of the stream where they feed heavily upon the substratum and associated biota, while juveniles are usually found in the dark water column under detrital patches, most likely employing a predator-avoidance strategy common in juvenile aquatic organisms (Werner and Gilliam, 1984). Vander Zanden and

TABLE 4

Trophic position of adult and juvenile $P$. sidneyi at both sites in the wet and dry seasons

\begin{tabular}{|l|c|c|}
\hline & Wet & Dry \\
\hline Mpophomeni Stream - Juveniles & $2.97( \pm 0.06)$ & $2.08( \pm 0.22)$ \\
\hline Mpophomeni Stream - Adults & $2.18( \pm 0.06)$ & $1.02( \pm 0.04)$ \\
\hline Lake Sibaya - Adults & $2.95( \pm 0.11)$ & $3.09( \pm 0.26)$ \\
\hline
\end{tabular}


Rasmussen (1999) described the progressive $\delta^{13} \mathrm{C}$ depletion as one moves from the littoral zone to the pelagic zone, to the profundal zone. There are various mechanisms to explain the $\delta^{13} \mathrm{C}$ variation along this gradient. The algal uptake of respired $\mathrm{CO}_{2}$, which increases in abundance from the littoral to the profundal zone, is reflected in the carbon isotope values of consumers at higher trophic levels (Rau, 1978). France (1995) showed an enrichment of benthic algae compared to phytoplankton due to the effects of a $\mathrm{CO}_{2}$ boundary layer which limits $\mathrm{CO}_{2}$ diffusion in benthic algae compared to pelagic algae, allowing for greater assimilation of $\delta^{13} \mathrm{C}$. The location of juveniles relative to adults within the shallow turbid stream means that juvenile crabs gain easier access to pelagic invertebrates, as they are also located within the $\delta^{13} \mathrm{C}$-depleted 'profundal zone' of the system. This may explain the difference in $\delta^{13} \mathrm{C}$ between adults and juveniles, while the access to a wider range of invertebrates would account for the greater trophic position and $\delta^{15} \mathrm{~N}$ signature of juveniles relative to adults.

In this study, support for the second hypothesis was obtained with a slight shift in diet observed between seasons and consumption of MPB and detritus generally more prevalent in the dry season. Variation in isotopic values is expected between seasons due to changes in rainfall, freshwater input and deposition of organic matter from allochthonous sources. Changes in dissolved inorganic carbon are influenced by the supply of $\delta^{13} \mathrm{C}$-depleted soil from surrounding areas, which increases during the wet season with a higher flow of freshwater throughout the system leading to greater soil movement (Lawrie and Stretch, 2011). Reduced photosynthetic activity during the dry season may also contribute to depletion of $\delta^{13} \mathrm{C}$ at this time (Farquhar et al. 1989; Anandraj et al., 2008). The increased freshwater inflow during the rainy season (summer, in this case) (Whitfield and Taylor, 2009; Lawrie and Stretch, 2011) results in an increased biomass of primary producers (Van der Molen and Perissinotto, 2011) and, subsequently, consumers (MacKay et al., 2010). Aquatic invertebrates, such as amphipods, gastropods, penaeid shrimps and bivalves, are found in the Mpophomeni Stream and Lake Sibaya habitats. Considering that $P$. sidneyi is an opportunistic feeder, it may feed more upon these aquatic invertebrates during the wet summer months. In the dry autumn/winter period, MPB and detritus are probably more pronounced in the crab diet due to the reduced numbers of aquatic invertebrates available during this time (MacKay et al., 2010). During the autumn/winter months productivity is low due to lack of rainfall, freshwater inflow, low temperatures and light availability (Anandraj et al., 2008; Whitfield and Taylor, 2009; Lawrie and Stretch, 2011). Nutritious food (e.g. MPB and aquatic invertebrates) is scarce and too energetically costly to find, while nutrient-poor detritus (Mann, 1988) is abundant and a better food choice in accordance with the optimal foraging theory (Macarthur and Pianka, 1966).

Both food webs appear to be largely based on allochthonous rather than autochthonous input. In the wet season, this is more pronounced at the Mpophomeni Stream, as $\delta^{13} \mathrm{C}$ values of consumers and detritus more closely match those of fringing and overhanging vegetation, while in Lake Sibaya detrital $\delta^{13} \mathrm{C}$ values incorporate those of both fringing vegetation and submerged macrophytes. This effect is reduced in the dry season, when MPB plays a more significant role in the diet of crabs and both allochthonous and autochthonous food sources are incorporated into the diet of $P$. sidneyi.

The consumption of the alien invasive gastropod Tarebia granifera (Lamarck, 1816) by P. sidneyi at Lake Sibaya is particularly noteworthy. Here, P. sidneyi may have previously fed on Melanoides tuberculata, a native gastropod that previously occurred around the lake (Hart, 1979). The absence of $M$. tuberculata is possibly due to competitive displacement by the invasive T. granifera (Raw et al., 2013) and crabs may now feed on T. granifera instead. However, preliminary studies indicate that this snail is tougher to crack compared to M. tuberculata (Miranda, unpubl. data). It is unlikely that the predator-prey interaction of the two species is a result of co-evolution as found in similar African ecosystems (West and Cohen, 1994, Marijnissen et al., 2009), due to the fairly recent introduction of $T$. granifera into the system. Coevolution between ancestors of the two species at a mutual site is also unlikely, as the evolution of Potamonautidae freshwater crabs (Klaus et al., 2011) most likely occurred on a separate continent to that of $T$. granifera (Genner et al. 2007). The proficiency with which $P$. sidneyi feeds on the bivalve C. fluminalis, also bearing a tough shell, indicates an adept handling ability that may be suitable for its predation upon T. granifera. Alternatively, the crab may opportunistically feed upon freshly dead molluscs (detritus), as T. granifera often become stranded at this site and die due to desiccation when the water level recedes. Potamonautes sidneyi may also feed on native gastropods such as Bulinus natalensis which have an isotope signature similar to that of T. granifera (Miranda and Perissinotto, 2012).

A large variation in the carbon isotope signature is expected for mixed carbon sources, such as POM and SOM, and has been observed in other studies (Richoux and Froneman, 2007). Carbon values of mixed sources also vary significantly between seasons with SOM, POM, MPB and detritus usually showing a great degree of $\delta^{13} \mathrm{C}$ depletion in the dry relative to the wet season at both sites. The elevated nitrogen signature of MPB at both sites (Tables 2 and 3) is unusual, as MPB is a primary producer. This has been recorded previously in the literature (Hobson et al., 1995; Lapointe et al., 2004; Richoux and Froneman, 2007), where nitrogen enrichment occurs in algal communities with an increase in land-based nitrogen run-off. This includes agricultural and sewage run-off from nearby sources. The Mpophomeni Stream is potentially subject to various sources of nitrogen pollution, including agricultural and domestic run-off from nearby farms and developmental plots, as well as the possible release of nutrients from deforested surrounding areas. This nitrogen pollution is then reflected in consumers (Xu and Zhang, 2012) and may explain elevated $\delta^{15} \mathrm{~N}$ values in MPB. The results of the GCA were used to eliminate some potential but unlikely food values from the stable isotope mixing models, indicating that SOM, detritus, animal and algal remains are part of the diet of $P$. sidneyi. GCA provides an insight into the most recent consumption by an organism. However, variations in digestion rates of different material, a phenomenon well-recorded in fish (Olson and Boggs, 1986; Olson and Mullen, 1986) and applicable to all organisms, may constitute a serious bias when attempting to quantitatively examine dietary intake using this method. For this reason, GCA is generally used in conjunction with SIA, as neither is without caveats (Hyslop, 1980; Gannes et al., 1997). Combined use of the two methods does provide a more accurate representation of diet over a relatively long-term period and also offers some idea regarding what portion of the ingested matter is actually assimilated.

The present study has shown that $P$. sidneyi adults and juveniles are associated with different trophic positions and habitats. These crabs are affected by changes in a wide variety of ecosystem processes and can, thus, provide general indications about ecosystem status. Globally, urbanisation and changes in 
land-use are occurring quite rapidly and subsequent pollution of aquatic systems is anticipated (Grimm et al., 2008). Several tributary rivers and streams around the iSimangaliso Wetland Park have recently become polluted with nutrients, agricultural toxicants and excess silt loading (Perissinotto et al., 2013). However, potamonautids appear to be fairly resistant to environmental change including heavy metal and organic pollution (Schuwerack et al., 2001; Darwall et al., 2009). Further changes include the effects of salinity on the distribution of freshwater crabs. While the Lake Sibaya population experiences a fairly stable freshwater environment, the St Lucia estuarine system is prone to extended flood and drought phases. During drought phases the increase in salinity causes a decrease in distribution of $P$. sidneyi around the lake. The ecological role of the species during a drought phase has not been investigated, although it can be expected that these crabs do not fulfil the same role under these conditions.

\section{ACKNOWLEDGEMENTS}

We thank the iSimangaliso Park Authority and Ezemvelo KZN Wildlife for supporting this project. This work is based on the research supported by the South African Research Chairs Initiative of the Department of Science and Technology (DST) and National Research Foundation (NRF) of South Africa. Any opinion, finding and conclusion or recommendation expressed in this material is that of the author(s) and the NRF does not accept any liability in this regard.

\section{REFERENCES}

ALLANSON BR (1979) The physico-chemical limnology of Lake Sibaya. In: Allanson BR (ed.) Lake Sibaya. W. Junk, The Hague. ANANDRAJ A, PERISSINOTTO R, NOZAIS C and STRETCH D (2008) The recovery of microalgal production and biomass in a South African temporarily open/closed estuary, following mouth breaching. Estuar. Coast. Shelf Sci. 79 599-606.

APPLETON CC (2012) Paragonimiasis in KwaZulu-Natal Province, South Africa. J. Helminth. 88 123-128.

BARNARD KH (1950) Descriptive catalogue of South African decapod Crustacea (crabs and shrimps). Ann. S. Afr. Mus. 38 1-837.

BRUTON MN (1975) Lake Sibaya - a land-locked estuary. Scientiae 16 $18-28$.

BRUTON MN (1980) An outline of the ecology of Lake Sibaya, with emphasis on the vertebrate community. In: Bruton MN and Cooper $\mathrm{KH}$ (eds). Studies on the Ecology of Maputaland. Rhodes University, Grahamstown.

BURRESS ED, GANGLOFF MM and SIEFFERMAN L (2013) Trophic analysis of two subtropical South American freshwater crabs using stable isotope ratios. Hydrobiologia 702 5-13.

CUMBERLIDGE N (2008) Potamonautes sidneyi. In: IUCN (2012) IUCN Red List of Threatened Species. Version 2012.2. URL: www. iucnredlist.org (Accessed 25 April 2013).

CUMBERLIDGE N, NG PKL, YEO DJC, MAGALHÃES C, CAMPOS MR, ALVAREZ F, NARUSE T, DANIELS SR, ESSER LJ and ATTIPOE FYK (2009) Freshwater crabs and the biodiversity crisis: Importance, threats, status, and conservation challenges. Biol. Conserv. 142 1665-1673.

DARWALL WRT, SMITH KG, TWEDDLE D and SKELTON P (2009) The status and distribution of freshwater biodiversity in southern Africa. IUCN, Gland, Switzerland and SAIAB, Grahamstown, South Africa. viii+120 pp.

DOBSON M (2004) Freshwater crabs in Africa. Freshwater Forum 21 $3-26$.

DOBSON M, MAGANA AM, MATHOOKO JM and NDEGWA FK (2007) Distribution and abundance of freshwater crabs (Potamonautes spp.) in rivers draining Mount Kenya, East Africa. Fund. Appl. Limnol. 168 271-279.
DYER DC, PERISSINOTTO R and CARRASCO NK (2013) Post-flood dietary variation in the Mozambique tilapia Oreochromis mossambicus in the St Lucia Estuary, South Africa. Mar. Ecol. Prog. Ser. 476 199-214.

FARQUHAR GD, EHLERINGER JR and HUBICK KT (1989) Carbon isotope discrimination and photosynthesis. Ann. Rev. Plant Biol. 40 505-537.

FRANCE RL (1995) Carbon-13 enrichment in benthic compared to planktonic algae: foodweb implications. Mar. Ecol. Prog. Ser. 124 307-312.

FORBES AT and HILL BJ (1969) The physiological ability of a marine crab Hymenosoma orbiculare Desm. to live in a subtropical freshwater lake. Trans. R. Soc. S. Afr. 38 271-283.

GANNES LZ, O'BRIEN DM and DEL RIO CM (1997) Stable isotopes in animal ecology: Assumptions, caveats and a call for more laboratory experiments. Ecology 78 1271-1276.

GENNER MJ, TODD JA, MICHEL E, ERPENBECK D, JIMOH A, JOYCE DA, PIECHOCKI A and POINTIER JJP (2007) Amassing diversity in an ancient lake: evolution of a morphologically diverse parthenogenetic gastropod assemblage in Lake Malawi. Molec. Ecol. 16 517-530.

GRIMM NB, FAETH SH, GOLUBIEWSKI NE, REDMAN CL, WU J, BAI X and BRIGGS JM (2008) Global change and the ecology of cities. Science 319 756-760.

HART RC (1979) The invertebrate communities: zooplankton, zoobenthos and littoral fauna. In: Allanson BR (ed.) Lake Sibaya. W. Junk, The Hague.

HILL M and O'KEEFFE J (1992) Some aspects of the ecology of the freshwater crab (Potamonautes perlatus Milne Edwards) in the upper reaches of the Buffalo River, Eastern Cape Province, South Africa. Southern Afr. J. Aquat. Sci. 18 42-50.

HOBSON KA, AMBROSE WG and RENAUD PE (1995) Sources of primary production, benthic-pelagic coupling, and trophic relationships within the Northeast Water Polynya: insights from ${ }^{13} \mathrm{C}$ and ${ }^{15} \mathrm{~N}$ analysis. Mar. Ecol. Prog. Ser. 128 1-10.

HOBSON KA, FISK A, KARNOVSKY N, HOLST M, GAGNON J-M and FORTIER M (2002) A stable isotope $\left({ }^{13} \mathrm{dC},{ }^{15} \delta \mathrm{N}\right)$ model for the North Water food web: implications for evaluating trophodynamics and the flow of energy and contaminants. Deep-Sea Res. II 49 5131-5150.

HYNES HBN (1950) The food of freshwater sticklebacks (Gasterosteus aculeatus and Pygosteus pungitius) with a review of methods used in studies of the food of fishes. J. Anim. Ecol. 1936-58.

HYSLOP EJ (1980) Stomach content analysis - a review of methods and their application. J. Fish Biol. 17 411-429.

KLAUS S and PLATH M (2011) Predation on a cave fish by the freshwater crab Avotrichodactylus bidens (Bott, 1969) (Brachyura, Trichodactylidae) in a Mexican sulfur cave. Crustaceana 84 $411-418$.

KIRKWOOD D and MIDGLEY JJ (1999) The floristics of sand forest in northern KwaZulu-Natal, South Africa. Bothalia 29 293-304.

KLAUS S, YEO DJC and AHYONG ST (2011) Freshwater crab origins - Laying Gondwana to rest. Zool. Anz. 250 449-456.

LAPOINTE BE, BARILE PJ and MATZIE WR (2004) Anthropogenic nutrient enrichment of seagrass and coral reef communities in the Lower Florida Keys: discrimination of local versus regional nitrogen sources. J. Exp. Mar. Biol. Ecol. 308 23-58.

LAWRIE RA and STRETCH DD (2011) Occurrence and persistence of water levels/salinity states and the ecological impacts for St Lucia estuarine lake, South Africa. Estuar. Coast. Shelf Sci. 95 67-76.

MACARTHUR RH and PIANKA ER (1966) On the optimal use of a patchy environment. Am. Nat. $100603-609$.

MACKAY F, CYRUS D and RUSSELL K-L (2010) Macrobenthic invertebrate responses to prolonged drought in South Africa's largest estuarine lake complex. Estuar., Coast. Shelf Sci. 86 $553-567$.

MANN KH (1988) Production and use of detritus in various freshwater, estuarine, and coastal marine systems. Limnol. Oceanogr. 33 910-940.

MARIJNISSEN SA, MICHEL E, CLEARY DF and MCINTYRE PB (2009) Ecology and conservation status of endemic freshwater crabs in Lake Tanganyika, Africa. Biodiv. Conserv. 18 1555-1573. 
MCCUTCHAN JH, LEWIS WM, KENDALL C and MCGRATH CC (2003) Variation in trophic shift for stable isotope ratios of carbon, nitrogen, and sulfur. Oikos 102 378-390.

MIRANDA NAF and PERISSINOTTO R (2012) Stable isotope evidence for dietary overlap between alien and native gastropods in coastal lakes of northern KwaZulu-Natal, South Africa. PLoS ONE 7 e31897.

MINAGAWA M and WADA E (1984) Stepwise enrichment of ${ }^{15} \mathrm{~N}$ along food chains: further evidence and the relation between $\delta^{15} \mathrm{~N}$ and animal age. Geochim. Cosmochim. 48 1135-1140.

MORRIS S and VAN AARDT WJ (1998) Salt and water relations, and nitrogen excretion, in the amphibious African freshwater crab Potamonautes warreni in water and air. J. Exp. Biol. 201 883-893.

NEL HA, PERISSINOTTO R and TAYLOR RH (2015) Effects of salinity on the survival of the Brackwater mussel, Brachidontes virgiliae, in the St Lucia estuarine system, South Africa. Water SA 41 15-20.

OLSON RJ and BOGGS CH (1986) Apex predation by yellowfin tuna (Thunnus albacares): independent estimates from gastric evacuation and stomach contents, bioenergetics, and cesium concentrations. Can. J. Fish. Aquat. Sci. 43 1760-1775.

OLSON RJ and MULLEN AJ (1986) Recent developments for making gastric evacuation and daily ration determinations. Environ. Biol. Fish. 16 183-191.

PARNELL AC, INGER R,. BEARHOP S and JACKSON AL (2010) Source partitioning using stable isotopes: coping with too much variation. PLoS ONE 5 e9672.

PEER N, PERISSINOTTO R, TAYLOR RH and MIRANDA NAF (2014) Temporal variations in the diversity of true crabs (Crustacea: Brachyura) in the St Lucia Estuary, South Africa. Afr. Invert. 55 39-65.

PERISSINOTTO R, TAYLOR RH, CARRASCO NK and FOX C (2013) Observations on the bloom-forming jellyfish Crambionella stuhImanni (Chun, 1896) in the St Lucia Estuary, South Africa. Afr. Invert. 54 161-170.

PETERSON BJ and FRY B (1987) Stable isotopes in ecosystem studies. Ann. Rev. Ecol. System. 18 293-320.

POST DM (2002) Using stable isotopes to estimate trophic position models methods and assumptions. Ecology 83 703-718.

POST DM (2003) Individual variation in the timing of ontogenetic niche shifts in largemouth bass. Ecology 84 1298-1310.

PURVES MG, KRUUK H and NEL JAJ (1991) Crabs Potamonautes perlatus in the diet of otter Aonyx capensis and water mongoose Atilax paludinosus in a freshwater habitat in South Africa. Z. Säugetierkd. 59 332-341.

RAU G (1978) Carbon-13 depletion in a subalpine lake: carbon flow implications. Science 201 901-902.

RAW JL, MIRANDA NAF and PERISSINOTTO R (2013) Chemical cues released by an alien invasive aquatic gastropod drive its invasion success. PLoS ONE 8 e64071.
REAVELL PE and CYRUS DP (1989) Preliminary observations on the macrocrustacea of coastal lakes in the vicinity of Richards Bay, Zululand, South Africa. Southern Afr. J. Aquat. Sci. 15 103-128.

REINECKE AJ, SNYMAN RG and NEL JAJ (2003) Uptake and distribution of lead $(\mathrm{Pb})$ and cadmium $(\mathrm{Cd})$ in the freshwater crab, Potamonautes perlatus (Crustacea) in the Eerste River, South Africa. Water Air Soil Pollut. 145 395-408.

RICHOUX NB and FRONEMAN PW (2007) Assessment of spatial variation in carbon utilisation by benthic and pelagic invertebrates in a temperate South African estuary using stable isotope signatures. Estuar. Coast. Shelf Sci. 71 545-558.

SCHUWERACK P-MM, LEWIS JW and JONES PW (2001) Pathological and physiological changes in the South African freshwater crab Potamonautes warreni Calman induced by microbial gill infestations. J. Invert. Path. 77 269-279.

STEENKAMP VE, DU PREEZ HH and SCHOONBEE HJ (1994) Bioaccumulation of copper in the tissues of Potamonautes warreni (Calman) (Crustacea, Decapoda, Brachyura) from industrial, mine and sewage-polluted freshwater ecosystems. Afr. Zool. 29 152-161.

VAN DER MOLEN JS and PERISSINOTTO R (2011) Microalgal productivity in an estuarine lake during a drought cycle: The St. Lucia Estuary, South Africa. Estuar., Coast. Shelf Sci. 92 1-9.

VANDER ZANDEN MJ and RASMUSSEN JB (1999) Primary consumer $\delta^{13} \mathrm{C}$ and $\delta^{15} \mathrm{~N}$ and the trophic position of aquatic consumers. Ecology 80 1395-1404.

WERNER EE and GILLIAM JF (1984) The ontogenetic niche and species interactions in size-structured populations. Ann. Rev. Ecol. Syst. 15 393-425.

WEST K and COHEN A (1994) Predator-prey coevolution as a model for the unusual morphologies of the crabs and gastropods of Lake Tanganyika. Arch. Hydrobiol. Beih. Ergeb. Limnol. 44 267-283.

WHITFIELD AK and TAYLOR RH (2009) A review of the importance of freshwater inflow to the future conservation of Lake St Lucia. Aquat. Conserv. Mar. Freshwater Ecosyst. 19 838-848.

WHITFIELD AK, BATE GC, FORBES T and TAYLOR RH (2013) Relinkage of the Mfolozi River to the St Lucia estuarine system urgent imperative for the long-term management of a Ramsar and World Heritage Site. Aquat. Ecosyst. Health Manage. 16 104-110.

WILLIAMS TR (1965) The diet of freshwater crabs associated with Simulium neavei in East Africa. III. - The diet of Potamonautes niloticus and of an unidentified crab species from Mount Elgon, Uganda. Ann. Trop. Med. Parasitol. 59 47-50.

XU J and ZHANG M (2012) Primary consumers as bioindicator of nitrogen pollution in lake planktonic and benthic food webs. Ecol. Indic. 14 189-196.

YEO DC, NG PK, CUMBERLIDGE N, MAGALHAES C, DANIELS SR and CAMPOS MR (2008) Global diversity of crabs (Crustacea: Decapoda: Brachyura) in freshwater. Hydrobiologia 595 275-286. 